\title{
'Kids sold, desperate moms need cash': Media representations of Zimbabwean women migrants
}

\author{
Aquilina Mawadza and Felix Banda
}

\begin{abstract}
The article draws on 575 randomly selected articles from the South African Media database to explore the representation of Zimbabwean women migrants. Using critical discourse analysis (CDA), the article shows that some of the dominant construction types depict a picture of caricatured, stereotypical and stigmatised Zimbabwean migrant women without voice and individuality. In turn, the diversity of their actualities is not captured in the process of constructing the twin images of Zimbabwean women as victims and as purveyors of decadent and other negative social ills in society. We conclude that Zimbabwean women migrants appear in the SA media primarily in three negative images: suppliers of sexual services, as un-motherly, and as victims. We also conclude that there is need for media to capture the voices of migrant women recounting their everyday lived experiences in different political and socio-economic contexts in order to account for the migrant women's voices of resilience, defiance and victimhood and of agency, against the normalising and marginalising influences of political institutions and national border controls. This would also help capture the transformative nature of migration to the women, the 'home' in Zimbabwe and the 'home' in South Africa.
\end{abstract}

\section{Context and background}

It has been reported that in 2008, 62 people were killed in areas around Johannesburg during the xenophobic attacks, which spread to other parts of the country, including Durban and Cape Town, while more than a hundred thousand were dislocated from their communities (Hammar, McGregor and Landau 2010). The recent ones starting in Durban in March-April 2015 spread to parts of Johannesburg. Like the previous xenophobic attacks, those most affected were Zimbabweans, Mozambicans and Malawians. Wakefield (2015) notes that of 5645 foreigners who 'have voluntarily left South Africa' after the March-April 2015 xenophobic attacks, 1440 were Zimbabwean nationals. It is not clear how many of these were women.

Hammar, McGregor and Landau (2010) are critical of the understanding and descriptions of mass displacement that focus on a linear track of cause-and-effect, which fails to account for the multidimensional nature of displacements. In their review of scholarship on displacements of Zimbabweans following the political meltdown and the dramatic collapse of the Zimbabwean economy in 2000, Hammar, McGregor and Landau (2010) see the consequences as transformative, not only in Zimbabwe, but also in the countries 
on which waves of migrants descended. In this article, following Hammar, McGregor and Landau (2010), we see 'displacement' as referring to general movement of people (voluntary or by force of circumstances) from one place to another, replacement of a people by another, an act of being forced out of a place and the distance of the trajectory between two places. Thus, displacement becomes a metaphor not just to describe issues of dispossession of 'home,' families and livelihoods; it is also a metaphor to describe new beginnings and hope in the diaspora. It also refers to the rejuvenation and the reshaping of patterns of consumption and production of goods and services, as well as political economies, which short circuits 'the conventional binaries-forced/voluntary, refugee/migrant, political/economic - used by states and international bureaucracies to define, categorise, manage and control migrants' (Hammar, McGregor and Landau 2010: 266). Whereas there is a need to recognise victims of displacement, and the humanitarian efforts that seek to curtail negative aspects of the displacement of people, there is also a need to recognise the opportunities, and how displaced individuals absolve themselves of the victim tag, and turn crises into opportunities. In essence, the multiple identities and the multifarious effects of the interactions between loss and gain in the contexts of crises arising from displacement require unpacking, lest a simplistic and normalising singular identity of victim that cloaks the different lived experiences of the any migrant Zimbabwean women is portrayed.

The purpose of this article is to explore the constructions of Zimbabwean women migrants and the extent to which the South African media (SAM) capture individual migrant women's socio-economic conditions and their shared agency. This entails finding out the extent to which Zimbabwean women's own voices of struggle and triumph against the political and socio-economic obstacles, and over the adversities resulting from institutionalised policing and marginalising government control systems, are heard.

We therefore need to unravel the extent to which some media, through choices of stories, discourse-types, story angles, word choices and so on, reframe and unfairly and without proof, directly or indirectly, associate the 'communicative contexts in which South Africans live, such as high crime rates, poverty, poor service delivery and lack of job opportunities' (Banda and Mawadza 2015: 61) with migrants. A comprehensive account of displacements of Zimbabweans into South Africa and elsewhere should necessarily account for voice and 'actorhood' by migrants rather than characterising them as victims in all situations. Following Banda and Mawadza (2015) and Hammar, McGregor and Landau (2010: 267), we shall argue that for comprehensive coverage, the SAM needs to account for the co-occurrence of the competing aspects of loss and gain and the mediating effects of agency in stabilising the opposing forces. This would entail the media giving opposing voices, such as the Zimbabwean migrant women themselves and social groups supporting migrant rights on the opposite side of the debate, a platform for expression (cf. Banda and Mawadza 2015).

\section{Gender profile of migration from Zimbabwe to South Africa}

Just as women's economic contribution to their families and communities has become increasingly significant, so too has women's presence in migration flows. This is reflected 
in the increasing percentages of women in migration flows to all world regions (Piper 2005: 3). Women migrants now constitute almost half (49.6\% in 2005) of all international migrants. This proportion has gone up from $46.6 \%$ in 1960 (Piper 2005). Although the percentage difference is small, the increase in women labour migration, i.e. of women moving in search of jobs, has caught the imagination of academics, the media and international and national policy makers across the globe. However, much of this attention has focused on migrant women who enter the lesser skilled sectors of the labour market, especially in work that is dangerous, dirty and low-paid. Academic research on, and media stories of, migrant women's employment usually focuses on sex work or domestic work. But this focus ignores the many other sectors of the labour market where women are also present, including the professional and skilled sectors.

Nyangairi (2010) cites literature to support the argument that women migration is not a recent phenomenon for Zimbabwean women. She cites Hungwe (2006) and Muzvidziwa (1997) who highlight the fact that even in colonial times there was rural-urban migration as well as cross-border migration of women to join their husbands or to seek 'economic opportunities for themselves' (Nyangairi 2010: 49).

Commenting on Zimbabwean women migration studies, Nyangairi (2010: 48) notes the tendency to characterise migrant women as 'separated, divorced, widowed and abandoned.' The agency and 'actorhood' of women in following their absent husbands and seeking economic independence through plying cross-border trade are seen as signs of desperation and moral decadence. In particular, single Zimbabwean women who migrate are often 'viewed with skepticism' and conflated with sex workers or 'prostitutes' Nyangairi (2010: 49).

In her study of Zimbabwean sex workers in Johannesburg, Nyangairi (2010: 150) warns against the conflation of all migrant sex workers as 'trafficked', as this 'silences the voices of some women who made rational but constrained decisions to enter sex work'. Her findings could not confirm the common-sense representation of Zimbabwean sex workers 'as victims, powerless, sexually harassed and oppressed' (150). Instead, she found agency and voice in the women, which revealed resistance to 'gender hierarchies and inequalities', as well as defiance against 'the double standard in society that privileges male sexuality above female's sexuality' (Nyangairi 2010: 251).

Although there is an impression created in the literature and media that women migration from Zimbabwe to South Africa has shown significant percentage increases in the past few years (see Banda and Mawadza 2015, and Nyangairi 2010 for critiques), according to Dodson (1998), cross-border migration in the region remains dominated by men. What seems the case is that the Zimbabwean population of South Africa has become more 'mixed' and diverse in recent years. This has made the women population more visible than before, especially with women more and more asserting their independence from men and taking up prominent roles traditionally preserved for men, such as providers for children and the family. In gender terms, there is an indication of the growing feminisation of migration from Zimbabwe as more and more women have left 
their country in search of work (Makina 2008). Zimbabwean women have few choices, giving most the option of staying in their country with little or no means of taking care of their families, or legally or illegally migrating to seek a new life and opportunities in South Africa.

According to Bloch (2005), traditionally migration from Zimbabwe was dominated by young single men looking for work in neighbouring countries, particularly South Africa. The deteriorating political and the declining economic situations make it imperative for households to diversify their livelihood and survival strategies. Bloch (2005) notes that one coping strategy has been the increase in cross-border travel for informal trade and the increase in Zimbabwean women going to South Africa and Botswana to sell items and to purchase goods in short supply for resale in Zimbabwe (Bloch 2005: 12). Table 1 shows more women than men involved in selling and buying as the reason for cross-border visits from Zimbabwe to South Africa.

It is also interesting that more men than women are 'visiting' for work or looking for work, and the women's visits are confined to mostly visiting family/friends and business.

Whereas a number of studies such as Lefko-Everitt (2010) and Bloch (2005) state that poverty, unemployment and economic hardship are, in recent times, the main migration 'push factors' for Zimbabwean women migrants, it needs to be remembered that the hardships are themselves the consequence of political decisions which included the appropriation of white farms. The imposition of economic sanctions on Zimbabwe by Britain and the USA, among other nations, was political as it was a reaction to a political decision by the Mugabe regime. What is also certain is that the migration of women workers from Zimbabwe has led to a partial reversal in traditional gender roles in the country, in that it was men who migrated for work purposes.

\section{Representation of women migrants in the media}

Literature on the construction of migrant women in the media is sparse. Research on migrant women and their experiences has been invisible in academic investigations. Scholars addressing migrant women issues deplore the lack of academic research in the field (Hellermann 2006; Catarino 2007), although some visibility has been gained of late. The lack of research on migrant women, as well as media coverage of the topic, are both reflections of academic as well as social marginalization of this issue. The migrant was assumed to be gender neutral (i.e. male), and historical studies of immigration, which tended to focus on the public sphere, ignored women who were confined to the domestic realm (Weinberg et. al 1992). 


\begin{tabular}{lcc}
\hline Purpose of visit & Men (\%) & Women (\%) \\
\hline Shopping, buying and selling goods & 32 & 65 \\
Work & 20 & 3 \\
Looking for work & 21 & 1 \\
Visiting family/friends & 11 & 16 \\
Business & 8 & 8 \\
Holiday & 3 & 4 \\
Medical treatment & 2 & 1 \\
School/College/University & 3 & 1 \\
\hline
\end{tabular}

Source: Zinyama (2002: 39)

Women in Southern Africa have often been portrayed as those 'left behind', and as 'passive rural widows who stayed put somewhere, practising subsistence, and later, cash crop agricultural production while their men departed, perhaps never to return' (LefkoEverett 2010: 287). The families and households of women migrants benefit significantly, particularly through remittances, which are largely used for basic necessities, including food, clothing and school fees. Migration is therefore viewed as a strategy for women to 'stand up and do things for themselves' (Lefko-Everett 2010: 271). Therefore, the migration of Zimbabwean women to South Africa is tied to their hopes for a better life. In the SAM, this desire for an improvement in their personal and economic situations is often recast as a deviant motivation for discourse of a better life.

While cross-border migrants are still predominantly men, there are a growing number of women choosing to become migrants in search of opportunities outside their home countries (Williams et al. 2002: 19). The largest proportion of women migrants in South Africa are from Zimbabwe, constituting $44 \%$ of all Zimbabwean migrants (Lefko-Everett 2010: 9).

Traditional gender biases and the masculinisation of migration make it difficult for single women to migrate. While those who travel legally through established border posts describe relatively few problems, those who 'jumped the fence' face a barrage of risks and rights abuses, including at the hands of paid guides and police and security officials. However, faced with extreme poverty at home, travel documentation is viewed as prohibitively expensive and irregular migration the only option (Lefko-Everett 2010: 287). Women migrants are exposed to the worst negative aspects of migration. LefkoEverett (2010) notes that despite their legal status, most migrant women in South Africa experience exclusion, harassment and verbal and physical abuse on a daily basis. They are also excluded from services such as healthcare, in spite of their constitutional right of access. As Banda and Mawadza (2015) and this article show, Zimbabwean women migrants are constructed in the media as coming to give birth in South Africa, overload the heal system and 'illegally' claim social grants for their children, in some cases where the children have been fathered by South African men. 


\section{Theoretical and methodological issues}

Here, we utilise CDA as a theoretical and analytical framework to examine how Zimbabwean women migrants are represented in the SAM. CDA offers the tools to reveal the discursive sources of power, dominance, social inequality, racial and political exclusions (Van Dijk 1989, 1991; Fairclough 1995; Wodak 2000a, 200ob). It provides the means to show how these discursive sources are maintained and reproduced within specific social, political and historical contexts. In this regard, Fairclough (1993) opines that CDA aims to systematically explore and lay bare opaque relationships of causality and determination between (a) discursive practices, events and texts, and (b) wider social and cultural structures, relations and processes; to investigate how such practices, events and texts arise out of, and are ideologically shaped by, relations of power and struggles; and to explore how the opacity of this relationship between discourse and society is itself a factor securing power and hegemony (Fairclough 1993: 135).

We are particularly interested in Fairclough's (1995) determination of text as sociocultural practice. Social practice may involve investigation at different levels of society, from the most localised to institutional or even wider societal contexts. Questions of power and ideology are dealt with at this level of analysis. Fairclough (1993) invokes two concepts, namely, interdiscursivity and hegemony. Fairclough (1993) says that interdiscursivity means 'an endless combination and recombination of genres and discourses', or 'the constitution of a text from diverse discourses and genres' (Fairclough 1993: 137). This means that a text contains traces of previous texts and restructures conventions to produce other texts. Incorporating the concept of interdiscursivity helps the critical discourse analyst account for the creative and heterogeneous aspects of a discursive event. For this article, interdiscursivity helps us trace the trajectory of texts and ideologies about Zimbabwean women migrants across different media, as well as the social, economic and other contextual factors associated with certain texts and discursive practices. Specifically, following Van Dijk (1991: 41) and Banda and Mawadza (2015), we use CDA to show how headline structures and leads may be implicated in the construction of a one-dimensional and simplistic identity for Zimbabwean women migrants. We show how the selection of relevant stories, sources of information (which often leaves out migrants' own voices) and how such news stories are packaged, reflects the underlying unequal power relations between locals and migrants. Banda and Mawadza (2015) argue that this may also be indicative of the kinds of practices by reporters and editorial staff which engender rather than curtail xenophobic discourses. In this sense, CDA assists to make the opaque aspects of discourse explicit and lucent.

The $S A$ Media's search engine (http://www.samedia.uovs.ac.za) affords a number of prospects for treatment of the data. Firstly, it permits searches using diverse word permutations and allows for the mining of articles on Zimbabwean immigration from several print media in the database. This feature allowed the authors to gain a relatively broad insight into how the media presents the issue of Zimbabwean immigration to South Africa, and formed the context of the analysis. Secondly, the search function was used to identify articles covering references to Zimbabwe, Zimbabwean, South Africa, $\mathrm{im} /$ migrant and im/migration, refugee, foreigner, women, female. The articles of 
interest spawned by the searches embrace reports, editorials and op-ed pieces. Headlines and content were scanned for linguistic constructions of female Zimbabwean migrants.

Although there have been sporadic outbreaks of xenophobic attacks in recent years, including the most recent during April-May 2015, the database used in the article consists of newspaper reports from 2000 to 2012. The data was extracted from reports on the socio-economic and political causes and effects of Zimbabwean immigration to South Africa. We took a random sample of five hundred and seventy-five (575) headlines and news stories from the $S A$ Media Database. The majority, representing $70 \%$, were published in five national newspapers, namely The Star $(n=134)$, the Mail and Guardian $(n=132)$, the City Press $(n=37)$, the Sowetan $(n=71)$, and the Sunday Times $(n=32)$. The extracts were obtained in full-text format and analysed for possible inclusion in the present analysis. Following other studies that have used critical discourse analysis, we focused on items that would expose opaque discriminatory material in otherwise innocent-looking discursive practices (Fairclough 1995; Van Dijk 1989, 1991; Wodak 2000a, 200ob).

In terms of analysis, CDA has been used to show how the media contribute to the social structuring of minority groups by camouflaging prejudiced discourses 'as neutral language of public discourse' (Li 2001: 28). Recently, in a study on moral panics and the representation of Zimbabwean migrants, Banda and Mawadza (2015: 52) use CDA to account for relationships between moral panics and related situational factors, and linguistic and other formal structures in which they are expressed'. They cite Van Dijk (1989: 29) who argues that the media, through their choices in 'specific discourse genres, communicative events, topics, styles, and rhetorics may influence the readers' perceptions and consumption of the news reports. Banda and Mawadza (2015) use the notions of topoi (Wodak 2000a) and moral panic (Cohen 2002) to show how news reports can feed into and out of the ideological and social contexts in which the news is produced and consumed. In particular, Banda and Mawadza (2015: 61) show how quotation is used to evoke 'immediacy', that is, that the Zimbabwean immigration problem is 'massive' and 'here and now', and that its veracity is unquestionable due to 'quoted' sources (some of whom were in reality dubious or 'unknown').

In this article, we show how the SAM reproduce biased discourses which construct Zimbabwean women migrants in a negative light through the '[s]tructures of headlines, leads, thematic organisation, the presence of explanatory background information, style, and especially the overall selection of newsworthy topics' (Van Dijk 1991: 41). Of particular interest for this article are those media discourse types that construct Zimbabwean women migrants as victims and transmitters of decadent behaviour.

\section{Linguistic representation}

\section{The sex worker}

Banda and Mawadza (2015) have illustrated the uncritical media coverage of Zimbabwean migrants in the SAM. This generates prejudices and stereotypes, rather than curtails them. The data analysis of the SA press coverage of Zimbabwean migrant women shows 
that words such as sex work are often associated with women migration from Zimbabwe. Here we see that biased choice of sample and topic angle results in the migrant women being portrayed in general terms in the media as always willing to engage in sexual activities for financial gain. However, even when such discourses are based on fact, the tendency is to sensationalise discourses to disproportionately over-blow their involvement in prostitution, ignoring socio-economic and other critical factors that triggered such behaviour in the first place. According to Nyangairi (2010), Zimbabwean migrant women engaged in sex work across borders became an object of sensationalised attention in the media. The most dominant image associated with women migrants from Zimbabwe is that of a supplier of sexual services. The women's own voices and trajectories to sex work, as well as their own voices about the experiences, gains and tribulations of the sex trade are missing from the discourses. The men who buy the services from the women are often not the subject of the discourse, thus reproducing male dominance and gender-based hierarchies and inequalities in sex work.

As a way of illustration, the SA media endorses and reproduces in their discourse a sexualized image of the Zimbabwean women when they state that they are highly sought after because they are 'cheap' and will sell their bodies for very petty items such as sugar or salt $(1,2)$ (see below). The presence of the man's voice in (2) constructs him as a victim of exploitation by women who charge too much for the service. It also seems that the women are there to make him have a great time for a few bars of soap.

In this construction, the SAM portrays Zimbabwean women migrants as ladies of the night who have chosen to work illegally in prostitution outside their own country. Such media constructions form public prejudice against them and hamper better understanding of the complicated hardship behind their lives (cf. Nyangairi 2010; Banda and Mawadza 2015). These women are presented primarily in the context of the sex industry in South Africa: sex workers trading sex for food (3), and the media often offer very little in terms of the appalling conditions in which they currently live and ran away from in the first place. This manner of coverage demonstrates the process whereby Zimbabwean women migrants are portrayed as 'others' who are foreign to South African society, are undermining morals and are 'threats to morality and social order' (Lemish 2000: 347). Other examples in the headlines or opening lines provide some sense of the choice of these references:

\section{(1) Zimbabwe: Sex for Soap, Salt and Sugar}

Susan - one of the sex workers frequenting the truck parks, who charges R5o (US\$6.50) for 'a short time' and R150 (US\$19.50) for the night. She says the growing number of sex workers was making it difficult to get these rates. The Sunday Independent, 3 August 2008.

(2) 'At times I can settle for R1oo for the night. It is better than nothing.'

'The women in South Africa are expensive, but across the border in Zimbabwe you can have a great time for a few bars of soap, and goods like salt and sugar.' The Sunday Independent, 3 August 2008. 
(3) Women trade sex for food

Poverty is forcing desperate Zimbabwean women and girls to sell their bodies for as little as a plate of pap or half a loaf of bread in the border town of Musina. The Sunday Times, 29 January 2009.

Zimbabwean women trading sex for food, or such petty grocery items as bars of soap, sugar and salt (1), and selling their bodies for a plate of pap1 or half a loaf of bread (3) relay images of desperation. This image is seemingly accepted in that the newspapers occasionally discuss the means by which the Zimbabwean women migrants make a living by selling their bodies (3) for basic necessities. Such media constructions that tend to blame the victim are pervasive in South African newspaper coverage. Little attention is given to contextualising these stories within the broad social processes in which they are located, i.e. the major difficulties (social, political and economic) in Zimbabwe that have led to this mass migration to South Africa. Comparatively, South African women are supposedly better than women from Zimbabwe because the women in South Africa are expensive, but across the border in Zimbabwe you can have a great time for a few bars of soap, and goods like salt and sugar (2). Such media constructions convey the message that South Africa is a better place in all respects. Zimbabwean women are cheap compared with their expensive counterparts in South Africa because you can have a great time for a few bars of soap, and goods like salt and sugar. Ironically, sugar, salt and soap are the basic necessities the women are so much in need of because of their economic situation. Zimbabwean women are also depicted as trading their bodies at any cost no matter how low the rate is: At times I can settle for R1Oo for the night. It is better than nothing (2). Evidently, there is no 'value' attached to these Zimbabwean women migrants as they are constructed as not valuing their bodies compared to South African women who charge much more. This is in sharp contrast to Nyangairi's (2010) study which found that these women not only negotiated terms for sex work, they also 'represented themselves as heroes at times and victims at other times, revealing the tensions in engaging with the good woman/bad woman binaries' (p.151). Even though the headings and stories occurred at different times and appear in two papers, the interdiscursivity, that is, the connections and 'recombinations' (Fairclough 1993: 137) are too apparent so that they appear as one connected story.

\section{Unfit mothers}

A 'motherhood' theme is particularly evident in the data. This theme is highlighted through the discussion of Zimbabwean women migrants as bad, irresponsible and unfit mothers. The construction of Zimbabwean women migrants in South Africa is expressed through the observation of a woman's deviation from the expected norms of a functioning wife and mother, both strongly embedded in African tradition, which treasures the family as the centre of cultural existence. Zimbabwean women migrants are constructed as doing unimaginable things that a 'normal' mother would not ordinarily do. The data shows that they rent, sell, abandon and even kill their babies. The representations of women drugging and renting babies (4-7) are expressed in such phrases as Drugged babies for rent in Joburg (4); ...believe the so-called 'mothers'; Babies are being bought and sold 
illegally on the streets of Joburg... (6) and ...desperate decision to strangle her 19month-old baby boy (7). It is interesting that what is missing from all these discourses are the fathers of these babies. The constructions are that the females have not complied with traditional feminine roles and are thus a threat to societal norms, much in the same way as being a prostitute or a sex worker. Women are thus unfairly singled out to be custodians of tradition and culture, while the men are absolved of their social and other responsibilities. The fathers of the children who are being sold are constructed as not being responsible because the women take the blame. Moreover, in line with CDA principles of uncovering prejudiced discourses (Van Dijk 1991, 1993; Li 2001; Banda and Mawadza 2015), the absence in the headline discourses of fathers as significant role players in families' well-being reflects the biased social structuring of family responsibilities. The women are constructed as being responsible for caring and bringing the child into the world, and for society's ills. As shown below, these women are constructed as not only involving themselves in wanton sexual acts with any man, they also rent out their babies, drug them, harm them, sell them and even kill them:

(4) Drugged babies for rent in Joburg

Some are for sale at R10 ooo a child

For only R2O a day you can rent a malnourished, handicapped and drugged baby and use it to beg from sympathetic motorists on street corners. A mother would have a different baby on different days. The women, mostly Zimbabweans, were living in Johannesburg's city centre in flats owned by Nigerians. The City Press, 23 May 2010.

(5) And doctors who have treated some of these babies believe the so-called 'mothers' may be deliberately drugging and harming these children to make them more compliant. The Star, 24 May 2010.

(6) Kids sold as desperate moms need cash.

Babies are being bought and sold illegally on the streets of Joburg for as little as R2O ooo The Star, 24 May 2010.

(7) Futility led me to kill baby

The overwhelming futility of a young Zimbabwean mother found herself in-unable to find employment and on being told she was not welcome in the home of her South African relative-led her to make a desperate decision to strangle her 19-month-old baby boy. Witness, 13 November 2009.

(8) Hospital cheffinds baby under a bush

The mother was Zimbabwean and had not been located. Social workers took the baby to the Princess Alice Adoption Home.

'It's very sad, the mother probably came to this country looking for a better life, but realised it wasn't the case and she couldn't care for the baby'. The Star, 18 September 2009. 
This representation of the unfit mother is amplified through stories relating to Zimbabwean migrant mothers renting their babies for a paltry R2o (approximately $\$ 2$ ), hence, for only R2O a day you can rent a malnourished, handicapped and drugged baby and use it to beg from sympathetic motorists on street corners. A mother would have a different baby on different days. The women, mostly Zimbabweans, were living in Johannesburg's city centre (4), and in addition these are malnourished or handicapped children. These are the babies that Zimbabwean women use at street corners to solicit money from motorists. The media also explicitly states that the women 'are Zimbabwean'. Apart from this, the Zimbabwean migrant women give birth to babies that they kill or dump in the bush and that end up in the hands of South African adoption homes. In this case, The mother was Zimbabwean and had not been located (8). Again the SAM makes it clear that the mother was Zimbabwean, but it is not clear how this fact was established. This induces a sense of lack of responsibility on the part of the Zimbabwean mothers, who give birth and abandon their babies, thereby placing a burden on South Africa. Most importantly too, these constructions of Zimbabwean women leaving babies in the care of South African social services perpetuates moral panic (Banda and Mawadza 2015).

Following Lemish (2000), the analysis provided suggests that the negative portrayals serve as a mechanism allowing the construction of otherness and the marginalisation of Zimbabwean women which tallies with the national discourse of Zimbabwean migration to South Africa. Presenting the Zimbabwean women in a stereotypical manner, through constructions of sexual immorality, expels them from the core of society. Polarised binary forms of representation, such as deviant 'whores and unfit mothers versus the expected definition of motherhood, are used to signify otherness' (Lemish 2000: 345). Such a marking of difference serves to maintain the symbolic boundaries by which the absorbing culture defines its identity. The threat of polluting the meaning of 'us' posed by the migrants' otherness is used to solidify the subjective sense of individuals as well as the culture as a whole (see Banda and Mawadza 2015 for media-induced moral panic). This mechanism is common to societies struggling with major social, cultural, and political splits (Hall 1997). As Hall (1997) observes: 'it sets up a symbolic frontier between the normal and the deviant, the normal and the pathological, the acceptable and the unacceptable, what belongs and what does not, between insiders and outsiders, Us and Them' (Hall 1997: 258).

\section{Migrant women as victims}

A study conducted by Lemish (2000) on the portrayal of Israeli women shows that a common role for women is that of victim (of violence, accidents and disasters). There is a vast amount of literature that has chronicled the construction of women migrants as victims in the media (see for example, Lemish 2000; Hellermann 2006; Catarino 2007; Lefko-Everett 2010; Nyangairi 2010; Banda and Mawadza 2015). The characterisation of women migrants as victims, rather than as successful, creative or active women, for example, is evident in SAM representations of Zimbabwean women migrants. For example, a number of Zimbabwean women who enter South Africa illegally across the Limpopo River are constructed as being raped and mugged. The victims are said to include teenage girls who are raped while they try to cross the border. It is also said that 
some of them are raped by armed people who also rob them of their belongings, including clothes. The following examples from the data demonstrate the point:

(9) Zimbabwean migrants raped, assaulted in SA stampede

The number of reported rapes and sexual assaults of Zimbabwean migrants to South Africa is increasing. The Star, 13 May 2010.

For example, excerpt (10) below shows Zimbabwean women as victims of gang rape.

(10) A Zimbabwean woman was left too terrified to go home after she was raped and robbed in Alexandra, The Star, 13 May 2008.

It is as if it is not enough to say 'Zimbabwean women were raped', the women were also 'assaulted' and 'robbed'. This victim conception is consistent with pre-existing stereotypes of foreign and migrant women globally. At the same time, it dramatises, sensationalises and trivialises what is a serious situation where migrant women are doubly vulnerable to violence insofar as they are exposed to violence. The violence reflects the status of women and gender inequalities both in the country of origin and the country of destination. Although the incidents in (9) and (10) took place two years apart, their intertextuality and interdiscursivity (Fairclough 1993) are uncannily overt to the extent that they read like extensions of the same story.

\section{Images of desperation}

Stories about Zimbabwean women struggling to legitimise their stay in South Africa are common (11) as they spend many hours or even days in queues at the Home Affairs offices applying for permits to enable them to stay in the country. Such stories are sometimes accompanied by visual images of Zimbabwean women migrants typically depicted in poverty, economic dependency and starvation situations. They are described as spending long hours with babies in the cold, making them vulnerable. Some women migrant victims of xenophobic violence in South Africa (11) are constructed as having no option but to stay in SA because of desperation. The following are examples:

(11) Around 300 Zimbabwean women, some with babies some as young as five weeks braved the wet cold weather and spent the night outside the city's Home Affairs office in the hope of obtaining a document that would allow them to live and work in the country for 12 months. Cape Argus, 22 May, 2009.

(12) Is there another country that can take us, was the desperate plea of a Zimbabwean woman living in the farming town of De Doorns in the Western Cape, after thousands of her countrymen fled xenophobic violence yesterday. The Times, 18 November 2009.

They are depicted as braving the immediate danger of adverse weather and possible harm to themselves or their families due to xenophobic attacks for the chance to live in South Africa. In (12) the woman is constructed as isolated and alone, while 'her countrymen' 
have 'fled'. She is constructed as so desperate that she has stayed put in the face of danger, wondering which country would take her, while the men have the sense to run away.

Zimbabwean women are also represented as seeking maternal healthcare in South Africa (13). Therefore, many of them were pregnant women (14), and arriving in South Africa, just in time to give birth. Apart from this, they register their children at the Home Affairs department, and then qualify for social grants. Therefore:

(13) Rather than simply escaping political tyranny, Zimbabweans illegally crossing the border now want the same benefits as South Africa's poorest-low-cost housing and child-support grants. The Star, 6 February 2006.

(14) Two weeks ago, 2300 illegal immigrants were arrested. Police were astonished to find that many of them were pregnant women. Musina Hospital spokesperson Phillemon Tlabane said there was a new phenomenon of heavily pregnant Zimbabweans arriving in South Africa, just in time to give birth. They then register their children at the Home Affairs department, even when the fathers were not South Africans. 'Once they have registered their children for social grants, they go back home to return only on pay days,' he said. TheStar, 6 February 2006.

Here we see the Zimbabwean women constructed as cunning and conniving by 'deliberately' falling pregnant and crossing the border to register their children for social grants in South Africa. These women leave their husbands in Zimbabwe every month to benefit from the social grants. Worse still, these women deprive poor South Africans of low-cost housing and child-support grants (13). It is interesting that a figure of 2300 migrants is given, but it is not clear how these figures were obtained. Banda and Mawadza (2015: 54) illustrate how the media may use "misleading statistical extrapolations and referencing aimed at showing an unabated "influx" of Zimbabwean migrants'. Word and phrase choices such as Zimbabweans illegally crossing the border now want the same benefits as South Africa's poorest (13), astonished, many, heavily pregnant and new phenomenon (14) function to exaggerate the number of women migrants and the enormity of the problem.

The women are so desperate that they cross crocodile-infested rivers in the dead of night, seek out relationships with South African men who are duped into helping them obtain South African IDs and social grants $(15,16)$.

(15) Out of desperation, she crossed the river and fence on her own one night in 2002. Not long afterwards she started a relationship with a South African man. The two are not married, but he is the father of her 5-month-old son and has agreed to help her with the application for a child grant. 'I applied for my identity book in 2002. Now my boyfriend is helping me to get a grant'. The Star, 6 February 2006.

(16) Everyone knows that in Musina, Zimbabwean women and even men marry under false pretences just for the sake of getting identity books. The Star, 6 February 2006. 
The media constructions of Zimbabwean women and their children indirectly benefitting from the South African healthcare and social grant system (13-16), depicts a desperate situation. Zimbabweans are unwelcome in this sense because they now want the same benefits as South Africa's poorest-low-cost housing and child-support grants (13). Zimbabwean women are also represented as fraudulently acquiring identity documents by marrying local South African men. The women are constructed as dubious and calculating by instigating a relationship with a South African man. She fell pregnant and had a baby immediately she arrived in South Africa. It is not just that the reporting is inaccurate by suggesting the woman crossing the river, her relationship with the South African man, the pregnancy and birth of a son took place in a short time; this also illustrates how through linguistic and thematic organisation of a story, media can obscure prejudiced discourses against minority groups (Van Dijk 1991; Banda and Mawadza 2015). Consider the flow of ideas in (15): she crossed the river and fence on her own one night in 2002. Not long afterwards.... relationship with a South African man. The two are not married...he is the father of her 5-monthold son...agreed to help her with the application for a child grant. First, this text is structured to shorten the time frames between the different events so as to cast doubt as to the identity of the father as the 5-month baby is constructed as having been born not long after her mother crossed the river. The nine months or so of her pregnancy appear unaccounted for, as they are obscured by the construction and appearance of her 5-month-old son, and not 'their 5-month son'. Second, the positioning in the unravelling argument structure of The two are not married, 5-month-old son and agreed to help her with the application for a child grant, are designed to show the woman as scheming and having conned the man into helping her access a child grant she was not entitled to.

Moreover, it does not only appear that the paternity of the child is in doubt; the construction-types the two are not married and she started a relationship further distance the South African man and the Zimbabwean woman and the child. The child, though fathered by a South African man is constructed as not deserving a child grant. When we juxtapose (15) and (16), it becomes apparent that that Zimbabwean woman is being constructed as trying to obtain an ID document under false pretences.

Oddo (2012: 74) argues that the media "can position audiences to regard their projections....as "based on real events..." and also, "offer viewers a seemingly self-evident context for understanding...discursive and material happenings'. In (14-16), we see this in quotations of unnamed police sources, the Musina Hospital spokesperson and lastly the construction Everyone knows.

\section{Discussion}

The dominant SA media perceptions are those of Zimbabwean women migrants as unskilled migrants. Yet there are many who are highly skilled professionals in various fields including education, medicine, engineering, architecture, to name a few. The images of Zimbabwean migrant women in the media as victims and suppliers of sexual services stereotype and stigmatise them as a group. The CDA of the portrayal of female 
migrants from Zimbabwe in the SAM suggests that they are presented mostly in a negative light and are located at the margins of society. The stereotypical construction of the women as victims and providers of sexual services, rather than helping their cause, robs them of agency and 'actorhood' as there is no interrogation of the reasons why the women risked their lives to cross borders in search of a better life for themselves and their families. In addition, as Nyangairi (2010) notes, the trajectories by those involved in sex work are either missing or not comprehensively interrogated. There has also been no acknowledgement of the positive contributions by migrant women. Indeed, as Peck and Banda (2014) and Banda and Mawadza (2015) note, in addition to some being employed in various highly skilled and professional fields, women from Zimbabwe and Malawi, for example, are treasured as child minders and domestic workers, arguably comparable to Filipino women in the United States of America. In some cases, these women are well aware of the market demands and are there to take advantage of it. The diversity of their realities is not captured in the media, which focuses on the images of women as victims and as purveyors of immoral and other negative social ills in society.

We have shown that in adopting particular editorial styles, for instance, not delving into an individual migrant's circumstances behind the migration and their everyday experiences, there is a danger of levelling the various and differentiated causes and effects of immigration. The almost universal labelling of Zimbabwean women as victims oversimplifies what are complex issues related to the causes and effects of woman displacement. A decision to leave one's home, family and community for what is often the unknown lifestyles in the diaspora cannot be reduced to suffering alone, and it is inconceivable that one would leave behind well-known routines and lifestyles at home to lead a life of destitution and be a victim in the new place. The construction of Zimbabwean women as essentially victims at home and abroad means the agency behind certain migration is lost and the positive aspects, including entrepreneurial and enterprising reasons for migration are left out of the discourses. There is no doubt that Zimbabwe's economy has suffered and that some of its citizens, including migrants, have been casualties of the effects of the negative aspects of displacement. However, as Hammar, McGregor and Landau (2010: 267) argue, displacement also has beneficiaries, and it has spurred 'new configurations and practices of power and accumulation [which have in turn] reshaped modes of governing and generated new economic logics, interests and relationships that can then act to prevent stabilisation, return, and settlement'. The new configurations of 'home' as a result of increased human, technological and cultural flows across national boundaries demand a different conceptualisation and discourse on citizenship. Just like discourses need to factor in the transgender roles in migration, a child born from Zimbabwean and South African parents should have equal rights to social benefits in Zimbabwe (if living in Zimbabwe) and South Africa (if living in South Africa).

Following Van Dijk (1989, 1991, 1993), we have also shown that certain headlines we examined appeared designed to make the reader react to Zimbabwean women migrants in a predetermined negative way. Here we focused on linguistic choices, which constructed Zimbabwean women migrants as victims and transmitters of debauched behaviour. It has been reported in the literature (Del-Teso-Craviotto 2009; Banda and Mawadza 2015) that 
despite their best efforts, the media may inadvertently perpetuate these stances against migrants through focusing on issues that construct migrants' identity along discourses of crime or delinquency, destitution or cultural conflict. Moreover, SAM's focus on Zimbabwean women migrants is a noble one as a way to make their predicament visible. However, the means of identifying them as a group that requires attention may unwittingly create norms and expectations which mark them as despondent, which would in turn come to define them as essentially dependent, and thus 'shroud individual and collective agency and forms of both resilience and resistance' (Hammar, McGregor and Landau 2010: 267). There is also a danger of creating moral panic that exaggerate the threat posed by Zimbabwean women migrants, who then become scapegoats and get blamed for the moral decadence and cultural dilution in society (cf. Cohen 2002; Banda and Mawadza 2015).

In this connection, a comprehensive account of flows of Zimbabwean women into South Africa and elsewhere should necessarily account for voice and 'actorhood' by migrants rather than characterising them as victims in all situations. Following Hammar, McGregor and Landau (2010: 267), we want to argue that for a comprehensive coverage, SAM need to account for the co-occurrence of 'mobility and confinement; dispossession and accumulation; impoverishment and wealth; destruction and transformation; loss and liberation'. The continuous interaction between these opposing counterpoints is transformative to individuals concerned, as well as to communities at 'home' and in their chosen spaces in the diaspora. Blommaert (2010: preface) in his monograph The sociolinguistics of globalization, argues for a sociolinguistics of mobility in which the world has become 'a complex "web" of villages, towns, neighbourhoods and settlements connected by material and symbolic ties in often unpredictable ways'. Mobile resources such as human, technology, and goods and services characterise the world (see also Pennycook 2007, 2010, 2012; Blommaert 2014). In this conceptualisation, we want to argue, 'locality' and 'home' are always shifting and mobile in line with movement, flows and trajectories of populations and technologies, for example. As new modes of citizenship and political economies become established, individual and group agency ensure that there is never a return to the stability and settlement of the past, but to unstable existence in the present re-settlement, in which the notion of 'home' keeps shifting between Zimbabwe and South Africa, depending on socio-economic and political conditions in space and time (cf. Hammar, McGregor and Landau 2010). Individual agency, in particular, becomes critical, as it becomes the means for managing the detrimental effects of the twin opposing counterpoints described above (cf. Hammar, McGregor and Landau 2010). It is also the tool by which migrant women's resilience and resistance are built to wrest control of national borders from the normalising and marginalizing influences of political institutions that have been created to monitor and restrict movement of people and goods.

However, news reporting such contradictory and complementary citizenships is sacrificed in preference for 'alarmist headlines, sensational news content, [news] angle and organisation of argumentation structure...which mutes immigrants' voices from the immigration debate' (Banda and Mawadza 2015: 60). It is not only the voices of women 
immigrants that are muted, those involved in the social welfare of migrants are not party to the debate. This means the discursive construction of Zimbabwean [women] immigrants as a social and economic nuisance is not challenged' (Banda and Mawadza 2015: 61).

Nyangairi (2010: 42) cites Magaisa (2001), who notes that although sexuality is premised on societal customary norms and morals, these appear to apply only to Zimbabwean women migrants. It is the woman who 'must be married to one man, bear him children, work for the home and be a good wife' (Magaisa 2001: 107). Mobility among men is seen as a sign of the masculine culture of exploring and providing for the family, while mobility among women independent of men is frowned upon, depicting moral decadence. Men can have different sexual partners and can even 'legally' have many wives in polygamous relationships. For a woman, sex is only moral and legal if done in marriage, and those who explore their sexuality outside the boundaries of marriage risk being labelled sex workers or prostitutes. Men are exempt from such regulations and labels (cf. Nyangairi 2010). Similarly, the identities of the men who fathered the children who are ostensibly being sold or abused by the women, and their roles in creating the situation in which these women find themselves are not a matter for scrutiny in the media. The men to which migrant sex workers provide services not only escape negative labels, they are also constructed as deserving the service for free or at the cheapest rate (e.g. at the price of salt and soap).

\section{Conclusion}

The research findings from this study indicate that Zimbabwean women migrants in the South African media are represented negatively in most cases. The results of our analysis suggest that Zimbabwean women migrants appear in the SAM primarily in three negative images: as suppliers of sexual services, as un-motherly, and as victims. Headlines and media reports of exceptional or successful professional Zimbabwean migrant women are almost non-existent.

When read in isolation, the texts appear innocent, and others might argue they express concern for the plight of Zimbabwean women migrants. However, when scrutinised interdiscursively from a CDA perspective, they reveal similar negative and monodimensional constructions of women migrants. The interdiscursive links are seen in similar or related headlines, story angles, lexeme choices, and sentence and paragraph structures. The interdiscursivity appears so strong that it sometimes appears the stories are a continuation of the same story or are a sub-text or sub-genre of journalistic writing.

We want to end with a plea for more research not just on the construction of women migrants in the media, but more especially on agency and 'actorhood' of such women in their quest for a guaranteed or an illusory future. There is also a need for more research that seeks to unravel the homogenisation of women migrants in the media, as well as that which explores the differences in modalities of lifestyles, social mobility and professional trajectories of women migrants across national and gendered employment practices.

\section{http://repository.uwc.ac.za}




\section{Note}

1 Pap is the staple food for most of the inhabitants of southern Africa and is called by different names in the different countries.

\section{References}

Banda F, Mawadza A. 2015. 'Foreigners are stealing our birth right': Moral panics and the discursive construction of Zimbabwean immigrants in South African media. Discourse \& Communication 9(1): 47-64.

Bloch A. 2005. The development potential of Zimbabweans in the diaspora: A survey of Zimbabweans living in the UK and South Africa. International Organisation for Migration Report. IOM Migration Research Series. No. 17. International Organisation for Migration: Geneva. pp. 1-98.

Blommaert J. 2010. The sociolinguistics of globalization. Cambridge: Cambridge University Press.

Blommaert J. 2014. From mobility to complexity in sociolinguistic theory and method. Working Papers in Culture Studies 103, 1-24. https://www.tilburguniversity.edu/upload/5ff19e97-9abc-45do-8773d2d8boagbof8_TPCS_103_Blommaert.pdf [Accessed on 10 June 2016].

Catarino C. 2007. New female migrants in Portugal: A state of the art working paper, No. 5 - WP4 February 2007. Centre National De La Recherche Scientific: Paris.

Cohen S. 2002. Folk devils and moral panics: The creation of the mods and rockers. London: Routledge.

Del-Teso-Craviotto M. 2009. Racism and xenophobia in immigrants' discourse: The case of Argentines in Spain. Discourse \& Society 20(5): 571-592.

Dodson B. 1998. Women on the move: Gender and cross border migration to South Africa. In: Field R (ed.), Southern African Migration Project: SAMP Policy Series. No. 9. Cape Town: Mega Print. pp. 436-454.

Fairclough N. 1993. Critical discourse analysis and the commodification of public discourse. Discourse \& Society 4(2): 133-68.

Fairclough N. 1995. Critical discourse analysis: The critical study of language. London: Longman.

Hall S. 1997. The spectacle of the 'other'. In: Hall S. (ed.), Representation: Cultural representations and signifying practices. London: Sage. pp. 223-279.

Hammar AJ, McGregor J, Landau L. 2010. Introduction. Displacing Zimbabwe: Crisis and construction in Southern Africa. Journal of Southern African Studies 36(2): 263-283. doi: 10.1080/03057070.2010.485779.

Hellermann C. 2006. Migrating alone: tackling social capital? Women from Eastern Europe in Portugal. Ethnic \& Racial Studies (29)6: 1135-1152.

Hungwe C. 2006. Putting them in their place: 'respectable' and 'unrespectable' women in

Zimbabwean's gender struggles. Feminist Africa 6: 33-47.

Lefko-Everett K. 2010. The voices of migrant Zimbabwean women in South Africa. In: Crush J, Tevera D (eds), Zimbabwe's Exodus. International Development Research Centre: Cape Town and Ottawa. pp. 269-290.

Lemish D. 2000. The whore and the other: Israeli images of female immigrants from the former USSR. Gender and Society 14(2): 333-349. 
Li PS. 2001. The racial subtext in Canada's immigration discourse. Journal of International Migration and Integration 2(1): 77-97.

Makina D. 2008. A profile of Zimbabwean migrants in Johannesburg. In: Johnstone S, Berstein A, de Villiers R (eds), Migration from Zimbabwe: Numbers, needs and policy options. Johannesburg: Centre for Development Enterprise. pp. 14-28.

Magaisa I. 2001. We came to the bridge for money. In: Hebnick P, Bourdillon MF (eds), Women, men and work: Rural livelihoods in south-eastern Zimbabwe. Harare: Weaver Press. pp. 103-116.

Muzvidziwa VN. 1997. Prostitutes: Vendors of another type. Journal of Social Development in Africa 2(2): 75-89.

Nyangairi B. 2010. Migrant women in sex work: trajectories and perceptions of Zimbabwean sex workers in Hillbrow, South Africa. (MA thesis). Johannesburg: University of the Witwatersrand.

Oddo J. 2012. Precontextualization and the rhetoric of futurity: Foretelling Colin Powell's UN address on NBC News. Discourse \& Communication 7(1): 25-53.

Peck A, Banda F. 2014. Dialogicality and imaginings of two 'community' notice boards in post-apartheid Observatory, Cape Town. Language Matters: Studies in the Languages of Africa 45(3): 360-377.

Pennycook A. 2007. Global Englishes and transcultural flows. London: Routledge.

Pennycook A. 2010. Language as a local practice. London: Routledge.

Pennycook A. 2012. Language and mobility: Unexpected places. Bristol: Multilingual Matters.

Piper N. 2005. Gender and migration. A paper prepared for the Policy Analysis and Research Programme of the Global Commission on International Migration. Singapore: Asia Research Institute.

Van Dijk TA. 1989. Structures of discourse and structures of power. In: Anderson JA (ed.), Communication Yearbook 12. Newbury Park: Sage. pp. 18-59.

Van Dijk TA.1991. Racism and the press. Routledge: London, New York.

Van Dijk TA. 1993. Principles of critical discourse analysis. Discourse \& Society 4(2): 249-283.

Wakefield A. 2015. Govt: Over 5 ooo foreign nationals chose to leave. News24. http://www.news24.com/SouthAfrica/News/Govt-Over-5-Ooo-foreign-nationalschose-to-leave-20150517 [Accessed on 19 May 2015].

Weinberg SS, Gabaccia D, Diner HR, Seller MS. 1992. The treatment of women in immigration history: A call for change. Immigration and Ethnic History Society 11(4): 25-69.

Williams B, Gouws E, Lurie M, Crush J. 2002. Spaces of vulnerability: Migration and HIV/AIDS in South Africa. Southern African Migration Project. Policy Series No. 24. Cape Town: Mega Print. pp. 1-56.

Wodak R. 2000a. Discourses of exclusion: A European comparative study. Speech at the Opening of the EU Observatorium, Vienna, 7/8 April 2000.

Wodak R 200ob. Discourse and discrimination: Rhetorics of racism and antisemitism. London: Routledge.

Zinyama LM. 2002. Cross-border movement from Zimbabwe to South Africa. In: Tevera D, Zinyama LM (eds), Zimbabweans who move: Perspectives on international 
migration in Zimbabwe. Cape Town: Southern African Migration Project. pp. 2641. 